\title{
Analyzing the Impact of Service Quality on Satisfaction in E-Banking Services- An Empirical Study 'S. Vijayanand, ${ }^{2}$ S. Logesh Kumar 1,2VET Institute of Arts and Science, Thindal, Erode vijayjaya2018@gmail.com
}

\begin{tabular}{|c|c|}
\hline \multicolumn{2}{|l|}{$A b$} \\
\hline \multicolumn{2}{|c|}{$\begin{array}{l}\text { Customer satisfaction is now taking as a core issue in all the service } \\
\text { oriented sectors and especially, banking institutions have considered this as a } \\
\text { base point due to heavy competition and proffering higher services through digital } \\
\text { and electronic mode. Even though they have offered better service, satisfaction } \\
\text { level towards these E-banking services among the customers is not dynamic } \\
\text { because of not having adequate knowledge among them in using these services } \\
\text { which clearly reflected the under usage of customer knowledge management by } \\
\text { the banking authorities. Taking into consideration, this study focusing the effect of } \\
\text { E-Banking Services on customer satisfaction particularly in Public sector Banks of } \\
\text { India through } 667 \text { customers selected through simple random sampling technique } \\
\text { by getting the opinion through self administered questionnaire. Tools like } \\
\text { Confirmatory Factor Analysis (CFA), Percentage Analysis, Karl Pearson's } \\
\text { Correlation, Multiple Regression Analysis, Comparing mean test were carried out } \\
\text { and the result revealed that there existed a positive association between the } \\
\text { factors under E-Banking Services and demographic variables too with the } \\
\text { Customer Satisfaction and all factors were highlighted as a forecaster for } \\
\text { Satisfaction. }\end{array}$} \\
\hline \\
\hline & \\
\hline & \\
\hline & \\
\hline
\end{tabular}

\section{INTRODUCTION}

One of the integral parts of ongoing strategy of fiscal organizations were delivering quality service in the e-banking services and constituting this as an essential ingredient for success and survival in today's aggressive environment. For the success of every organization, quality in services is mandatory to gain the 
customer satisfaction. If there is any deficiency in the services, deflection rate among the customer will be increased due to availability of competitive services.

(Sanli \& Hobikoglu, 2015) highlighted that Electronic Banking is a channel that provides anywhere and anytime banking services to the customers technically as well as customer friendly since 1997 and gained a speed from 2000 to till date. (Chikwe \& Uduma, 2010) were also highlighted that this e-banking services has got a very good attention worldwide within a short span of time due to its technological process particularly in financial market and drastically changed the business environment removing the border of transaction and brings many innovative business and opportunities.

(Sanli \& Hobikoglu, 2015) also highlighted that it was only the advance technologies that was the source for overcoming the interbank competition. Even completing two decades, still there exist problem in the e-banking services and the expectation of the customers has not been fulfilled and as advised by (Sharma et al. 2020) that the banking service providers have to make plan and work out the strategy for improvising the service based on the expectation of the customers.

(Ali \& Omar, 2016) in their study informed that the startup cost for the banks was found to be high in the e-banking set due to installation of various technological interface and this may be the reason for non-extension of the services to the rural area which has coincidence with the findings of (Sangeetha \& Myilswamy, 2020) who highlighted that the service providers should concentrate on the rural side where lack of knowledge about the e-banking services is noticed.. (Usha, 2012) in the work results have informed that it is the prime work for every banking sector to make aware and educate the customer towards proper securing of password, logging out after every transaction for their safety and security.

Besides this popularity and the knowledge of knowing the services, numerous other risks were also involved in the e-banking like Security, data confidentiality, system integrity, risk of action due to the third parties which lead to legal risk. (Munir,2017) particularly explained the financial loss due to connectivity problem during online transactions. Despite of these barriers in the services, all the banks were witnessing successful implementation and gaining satisfaction through their relationship among their customers through their efficiency and the effectiveness. But the degree of the satisfaction is not realized among those customers. (Graefe \&Burns, 2013) in (Salim, 2018) argued that service quality is essential to all the organizations as it is closely interrelated and associated with the customer satisfaction. Therefore, every bank has to give attention to improve the accessibility through service delivery and thereby improve the customer service through new and updated technology.

Taking into consideration, this study has considered the primary objective as analyzing the impact of the e-banking services and its service quality on the customer satisfaction through important factors pertaining to customer satisfaction 
like Responsiveness, Convenience and Security especially in the Public Sector banks in India with the following research questions.

1. Whether the performance of e-banking services in the public sector banks fulfilling the customer needs?

2. Whether the banking sector yields a very good satisfaction level among the customers through their features of e-banking services?

3. Whether Customer Relationship Management has been successfully implemented in the banks by penetrating the knowledge about the services and thereby created a strong relationship with them?

\section{LITERATURE REVIEW}

Many earlier research has witnessed may work on the customer services, Satisfaction and loyalty along with the customer trust in the banking sector in various Nations.

According to (Zavareh et al. 2012), there existed a significant positive relationship between the efficient and reliable services, fulfillment, security, trust, responsiveness, site aesthetics and ease of use with the e-Customer Satisfaction and substantiated by (Ashtiani et al. 2017) who highlighted that only increase in the customer satisfaction and loyalty increases the cross buying of the product. But at the same time, (Narayana et al. 2013) argued that organization need to give prominence due towards core services, Resolution the problem, cost saving, convenience, Risk and privacy concern so as to yield the consumer satisfaction and continuation

(Buddhika \& Gunawardana, 2020) discovered that the constructs such as ATM, online banking, credit card and debit card have positive impact on customer satisfaction, but it is the telephone and mobile banking found negative impact with them. (Rajam et al. 2013) informed that satisfaction among the customers through online banking is accomplished only through rapid changes in the technology in terms of quality, accessibility, interactivity and friendly relationship. This is in line with the findings of (Rajput, 2015) who have pointed out that 45 percent of the customers were having positive perception towards e-banking services and most of the people were not utilizing the service because of inadequate knowledge about the usage and the system. According to (Kelly \& Palaniappan, 2014) regarding the mobile banking, there found lapses in the level of security which influenced the customer attitude, perception and behavior and satisfaction in accepting the mobile technology in internet banking. Purposefully with the version of (Singh \& Bassi, 2017) who informed that banking website found significantly associated with the trust factors and the customer loyalty and despite of moderate service quality, the bankers keeping the customers with loyalty through other factors like keeping the promises already given to the customers and also agreed by (Sathiyavany \& 
Shivany, 2018) with their findings about the significant relationship between the eservice quality, e-customer satisfaction ,e-customer loyalty and the personal factors.

Internet banking is mostly preferred by the female customers in Philippines and most of the customers were satisfied with the speed and accuracy of the transaction, convenience and the security as they have enough knowledge in handling the online banking (Kervin \& Mojares, 2014). (Kodithuwakku, 2018) in the study highlighted that the transaction-based factors like cost, security Assurance, Reliability, Availability of transaction type and usefulness and Technology based factors like Responsiveness, User Friendliness, Speed and Availability have significantly impact on the customer satisfaction.

There found a strong relationship between quality in services, contentment and faithfulness among the clients in the private bank in Chennai out of which significant relationship found between Responsiveness, Customer Relationship and Service Quality (Jenifer \& Rao, 2018). Purpose of using the e-banking facilities by the customers in the rural area of Odisha, India was to track easily the banking transaction activities and majority of the customers were found satisfied towards security and privacy in e-banking services offered by the concern banks (Panda \& Misra, 2017).

(Nor et al. 2012) informed that factors like intention to accept technology, trust and security have influencing the individual towards e-banking services except the security in safeguarding the confidential information in the Romanian banks and (Yee \& Faziharudean, 2010) pointed out that factors like Trust, Habit and Reputation have positive influence towards internet banking and service quality and customer loyalty found having negative influence towards the website usage. (Saravanan \& Leelavathi, 2020) found that efficiency, privacy and the website design have contributed more towards the customer satisfaction in e-banking services but at the same time, awareness of this service found very low with the rural people.

Customer service has the positive influence on trust of the mobile banking users and if there is better customer service, the trust among them will go on increasing and it have the positive association towards the customer satisfaction and the loyalty (Johannes et al. 2018). Web design, contact, speed and convenience factors were having positive relationship with internet banking but at the same time, there is no positive relationship found with the security, service quality and the privacy with the satisfaction level. Bankers need to analyze the user's opinion through their perception and derive the solution for that so as to improve the satisfaction level through all factors considered (Ling et al. 2016). Reliability in E-Service quality has strong relationship with customer satisfaction In the Lebanon banks (Hammoud et al. 2018). There was a significant impact of accessibility, Web design, privacy, Usefulness, Ease of Use and accessibility on the level of customer loyalty in the commercial bank of Jordan (Alhawary et al. 2017). Customer retention, Security, Virtual banking and Technology invasion were the key 
determinants of Customer loyalty out of which customer retention is emerged as a predictive factor for the loyalty (Kaur \& Kiran, 2014). There is a significant association between the competency and the efficiency, accuracy and relevance and effective management of management portal and website in the public sector banks in Kerala state, (Sunith, 2019).

From the above points, it is clear that the customer could get satisfied only when all the relevant factors pertaining to service quality should be consistent and one important thing is the role of customer relationship management through which the customer could be educated and informed about the features and the facilities of e-banking services. Unless or otherwise it is not implemented, banks could not expect more customers towards e-banking services which is their prime objective in their vision and mission. Many research studies as mentioned above were conducted with various factors but only a smaller number of studies were conducted in India that too not considered the factors like Responsiveness and Convenience with security as the mediating factor to evaluate the customer satisfaction level among the customers. This is the actual research gap identified for this study and executed with the public and private sector banks in India.

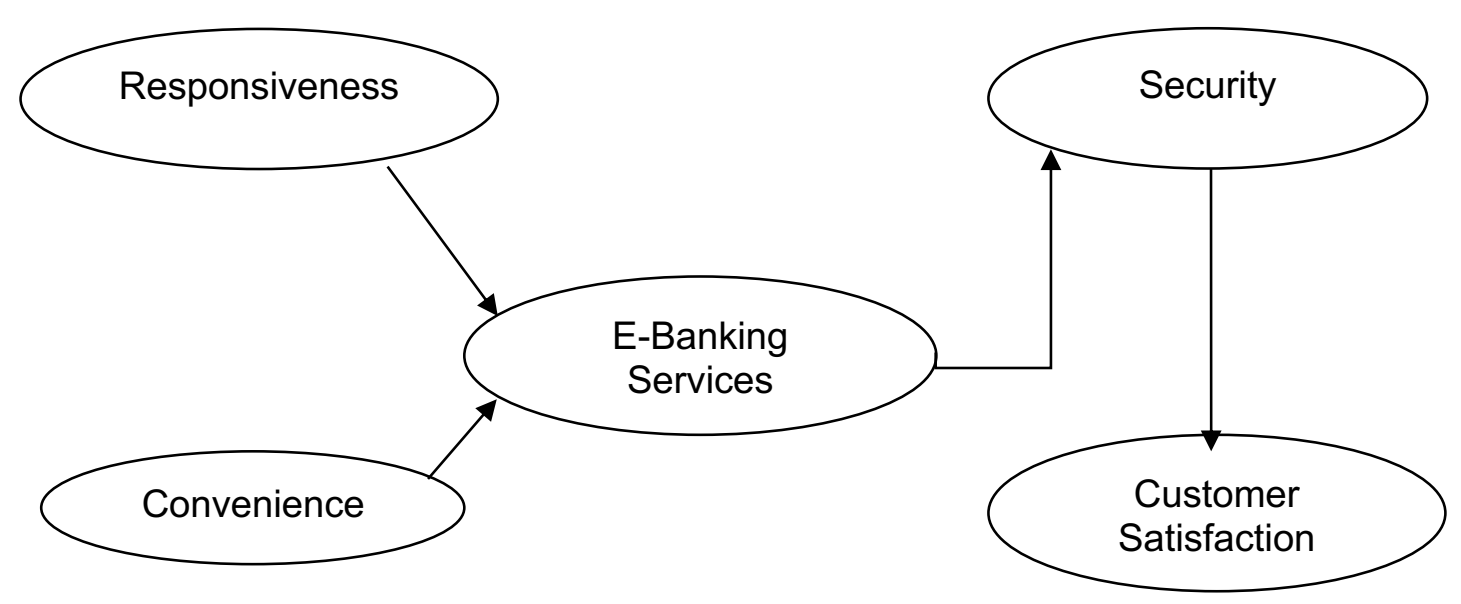

Figure 1. Conceptual Model

The objectives of the study are:

1. To find the association between the demographic variables and the factors under e-banking services and Customer Satisfaction.

2. To investigate the factors of e-banking services that influence the level of Customer satisfaction 
3. To know the association between among the various factors influencing the customer satisfaction in e-banking services

4. To study the impact e-banking services on Customer Satisfaction.

5. To analyze the mediating role of Security between the e-banking services and the customer satisfaction.

\subsection{Formulation of Hypothesis}

Hypothesis $1\left(\mathrm{H}_{1}\right)$ : There exist an association between the demographic variables and the factors that influencing the e-banking services and the customer satisfaction.

Hypothesis $2\left(\mathrm{H}_{2}\right)$ : Responsiveness of e-banking services has a positive impact on Customer Satisfaction.

Hypothesis $3\left(\mathrm{H}_{3}\right)$ : Convenience of the e-banking services has a positive impact on Customer Satisfaction

Hypothesis $4\left(\mathrm{H}_{4}\right)$ : Security under e-banking services has a positive impact on Customer Satisfaction

Hypothesis $5\left(\mathrm{H}_{5}\right)$ : Security factor mediating the effect of e-banking services on the customer Satisfaction.

\section{METHODOLOGY}

\subsection{Scope of This Study}

This study is descriptive and purposely conducted to study the impact of the various factors that influencing the e-banking services on the level of customer happiness in the fiscal institutions especially in Public Sector banks. There are large numbers of Public Sector and Private sector banks situated India especially in all the rural and urban area. As on 30.06.2019, it has been informed that there were 32083 private banks out of which 6846 were positioned in the Rural areas and in respect of public sector banks, there are 33827 constituted by 4 major banks like SBI, Syndicate bank, UCO bank and Union bank of India (Source: Internet) and these branches offers services through digital mode to all their clients. While seeing the database, more branches of public sector banks are operating then private sector banks and there is a question "whether the e-banking services being offered by the Public sector banks are on par with the private sector banks?" And there exist a huge opportunity to study the present scenario of implementation in those banks in India. 


\subsection{Sample Collection}

This study is descriptive and purposely conducted to study the impact of the various factors that influencing the e-banking services on the level of customer happiness in the fiscal institutions especially in Public Sector banks. There are large numbers of Public Sector and Private sector banks situated India especially in all the rural and urban area. As on 30.06.2019, it has been informed that there were 32083 private banks out of which 6846 were positioned in the Rural areas and in respect of public sector banks, there are 33827 constituted by 4 major banks like SBI, Syndicate bank, UCO bank and Union bank of India (Source: Internet) and these branches offers services through digital mode to all their clients. While seeing the database, more branches of public sector banks are operating then private sector banks and there is a question "whether the e-banking services being offered by the Public sector banks are on par with the private sector banks?" And there exist a huge opportunity to study the present scenario of implementation in those banks in India.

\section{RESULT AND DISCUSSION}

Confirmatory Factor Analysis (CFA) is one of the foremost methodologies to find the construct validation and being used in most of the research studies probably when the tests are supposed to be multidimensional (Prudon, 2015). This method also facilitated to confirm the Uni-dimensionality, latent factor structure, goodness of fit index for the proposed model along with the testing of multiple hypotheses pertaining to the study (Hoyle 2004). The test of hypothesis concerning the confirmatory factor analysis could be performed using latent variables structural equations to confirm the fit of the model (Chau, 1997, Sun, 2005). In this study also, CFA was carried out values were obtained through SEM of AMOS pertaining to the study is detailed below: It has been observed that all the goodness and badness indices are met by the measurement model $(\mathrm{CMIN}=582.139$, Degree of Freedom: $146: \mathrm{x} 2 / \mathrm{df}=3.987, \mathrm{GFI}=0.896, \mathrm{AGFI}: 0.864, \mathrm{IFI}=0.924, \mathrm{TLI}=0.920, \mathrm{CFI}=0.923$, $\mathrm{NFI}=0.905, \mathrm{RMR}=0.050, \mathrm{SRMR}=0.0510, \mathrm{TLI}$ and RMSEA $=0.074)$. The detail of the Parameter estimates and other values of Average Variance Extracted (AVE) and the Composite Reliability (CR) are given in Table 1 (Appendix). 


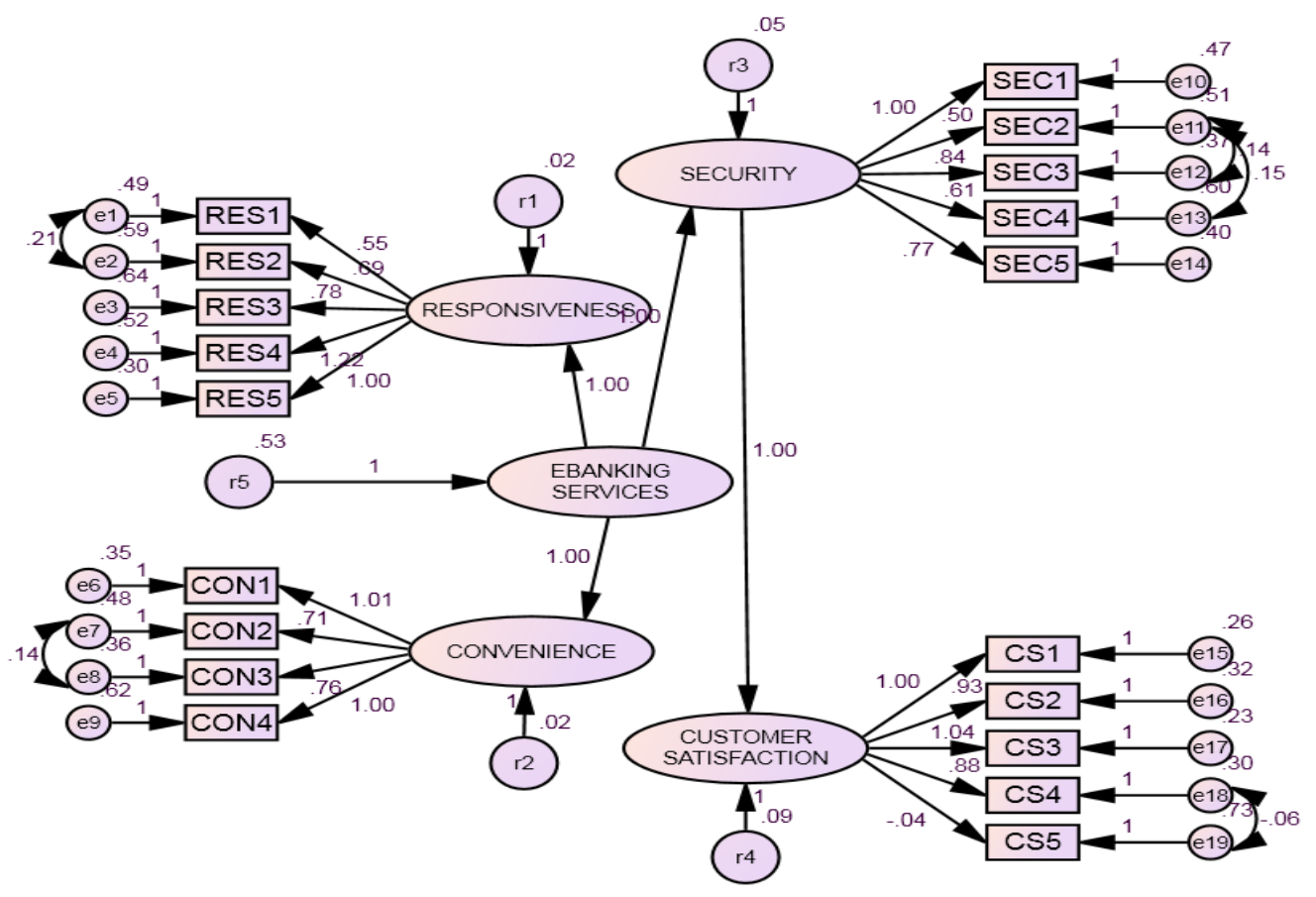

Figure 2. Structural Equation Modeling Results

Regarding the Reliability, it is found that the value of the Cronbach Alpha value were found to be more than the acceptable value of 0.70 (Nunnally, 1978) (i.e.) 1) Responsiveness: 0.795; Convenience: 0.792; Security: 0.815; and Customer Satisfaction: 0.785 ) and thereby confirmed that the variables taken in this study were found highly reliable and replicated the positive relationship among them. The value of the R2 also represented the significant positive relationship among the constructs and the indicators taken up for consideration for this research. Regarding the Composite Reliability $(\mathrm{CR})$ of the factors, all the constructs were having the value above the recommended level (i.e.) $>0.70$ (Responsiveness: 0.943: Convenience: 0.925; Security: 0.934; Students Satisfaction: 0.974) thereby confirmed the internal consistency of the model and the factors as indicated by (Hair et al.1998). Regarding Extraction of Average Variance (AVE) which indicated the error due to the variance in the measurement of the data, from the value of the study, (Responsiveness: 0.450; Convenience: 0.466; Security: 0.430; Customer 
Satisfaction: 0.54) which are providing the further evidence of reliability and free from measurement error as prescribed by (Hair et al. 1998).

\subsection{Demographic Profile of the Respondents}

As Demographic variables plays a significant role in using the e-banking services among the respondents, various socio demographic factors were considered in this study and the result revealed is tabulated in Table 2 (Appendix).

Regarding the demographic profile of the customers under e-banking services, from the result, it is revealed that maximum respondents were found to be Male with 67.8 percent and maximum were found under the age group of 21-35 years. Regarding the educational qualification, it is seen that 33.3 percent of the customers were found completed Graduation. Most of the customers were working in Private sector $(60.3 \%)$. 317 respondents with 47.5 percent were residing in the urban area and 296 respondents with 44.4 percent were having their residence in the rural area. Most of the respondents were having only 1-5 years' experience with their banks. 317 customers to the tune of 47.5 percent were having savings account. Due to the implementation of the e-banking services, regarding the frequency of visit, it is noticed that 40 percent of the total population were visiting their banks rarely and next to this, 30.1 percent of the customers were visiting the bank on weekly basis.

\subsection{Association between the factors that influencing E-banking Services and the Customer Satisfaction in Public Sector Banks through Karl Pearson's Correlation}

To analyze the inter correlation between the various factors of e-banking services that influencing the satisfaction level of the customers of public sector banks, the, Karl Pearson method was conducted, and the result is presented in Table 3 (Appendix).

From the result, it is confirmed that factors like Responsiveness, Convenience, Security and Customer Satisfaction were found positively correlated with each other at $1 \%$ level of significance All the factors were found to have strong and considerable high correlations with each other $(R=+0.60$ to +0.70$)$ and hence the performance of each factor were found to be similar in the study of (Schober et al. 2018). The highest correlation is found between "Responsiveness" with "Customer Satisfaction" with the value of $\left(r=-0.759^{* *}\right)$ at $1 \%$ level of significance and the lowest correlation was found between "Convenience" and the "Security" with the value of $\left(r=0.656^{* *}\right)$ at $1 \%$ level of significance. Through the R2 (Coefficient of Determination) value, $58 \%$ variation was shown by the Responsiveness: $50 \%$ by Convenience and $48 \%$ by the Security factors with the Customer Satisfaction. 


\subsection{Multiple Regression Analysis between the factors that influencing the E- Banking services in the Public Sector Banks and the Customer Satisfaction}

In order to analyze the impact of the factors considered under the E-Banking services like Responsiveness, Convenience and the Security among the customers of the Public Sector Banks in India, multiple Regression Analysis was carried out by considering the Customer Satisfaction as the dependent variable and factors like Responsiveness, Convenience and the Security as independent variable. The details of analysis are showed in Table 4 (Appendix).

From the result of the Multiple Regression Analysis, the value of the " $F$ " was found to be 424.625 which is significant at $1 \%$ level of significance and this witnessed the overall acceptance of the model considered and the value of the Beta (i.e.) Responsiveness $(B=0.397)$, Customer Satisfaction $(B=0.300)$ and Customer Trust $(B=0.249)$ showed the important of the independent variable on the changes in the dependent variable (i.e.) Customer Satisfaction In addition, all the independent factors were highlighted as the significant forecaster for the customer Satisfaction and the value of R2 also confirmed it with a way that a unit increase in the independent variable increases the dependent variable (Customer Satisfaction) to the tune of 65.6 percent. From the value of Durbin Watson (2.037) and the Tolerance value and Variance Inflation Factor, it is confirmed that there was no multicollinearity noticed among the factors and variables.

\subsection{Association between the Demographic Variables of the study and the factors that influencing the E-Banking Services in Public Sector Banks in India}

To find the association between the demographic variables considered in this study and the factors that influencing the E-banking Services and the Customer Satisfaction, Paired sample " $\mathrm{t}$ " Test and the One-Way ANOVA - "F" test were carried out.

Regarding the association between the demographic variables of the respondents of this study and with the factors that influencing the E-Banking Services and the customer satisfaction, From the result, it is revealed that the Gender was significantly associated with all the factors as the " $\mathrm{t}$ " value is significant at $1 \%$ level. While considering the association between the factor Responsiveness under E-Banking Services and the demographic variable, it is only the Experience, Type of Account and the Frequency of Visit were found statistically significant at $1 \%$ and $5 \%$ level. Regarding the association between the Convenience factor and the demographic variables, all of them were found significantly associated except the variable Educational Qualification and the Type of the Account of the respondents. Regarding with the Security factor, it is noticed that the variable like Age, Experience with the bank and the Frequency of visit were found significantly 
associated at $5 \%$ level of significance. Regarding the association with the Customer Satisfaction, variables like Occupation, Status of the Residential Area, Experience and Frequency of Visit were found significantly associated at $1 \%$ and $5 \%$ level of significance.

\subsection{Discussion and Implications}

The primary objective of the study is to analyze the impact of the E-banking Services on Customer Satisfaction in Public sector banks in India among the 667 respondents who were the customers in that bank selected under simple random sampling method. From the findings of the study, it is revealed from the goodness of fit indices through structural Equation Modeling of AMOS, the model found good as the indices values were found under the limit prescribed in the earlier research. Regarding the association between the demographic variable and the factors under E-Banking Services and the customer satisfaction, there occurred a significant association between them and thereby confirmed the alternative hypothesis $(\mathrm{H} 1)$. Regarding the association between the Responsiveness and the Customer Satisfaction, it is noticed that there is a significant correlation found between the factors as the " $r$ " value is found to be $(r=0.759)$ and it also highlighted as a significant forecaster to the customer satisfaction there by confirmed the alternative hypothesis $(\mathrm{H} 2)$ which has substantiated and consistent with the findings of (Sathiyavany and Shivany, 2018)., (Kodithuwakku, 2018) and (Jenifer and Rao, 2018) Regarding the association between the convenience and the customer satisfaction, it is seen that there existed a positive correlation between the factors as the " $r$ " value is found to be $(r=0.705)$ and also highlighted as a significant predictor to the customer satisfaction and there by accepted the alternative hypothesis $(\mathrm{H} 3)$ which is consistent with the findings of the study of(Kervin and Mojares, 2014) and (Ling et al 2016) : ( Kaur and Kiran, 2017).

Regarding the association between the security and the customer satisfaction, it is confirmed that there was a positive correlation found between the factors as the " $r$ " value is found to be $(r=0.691)$ and also highlighted as a important predictor for the satisfaction level among the customers and thereby accepted the alternative hypothesis (H4) which substantiated the findings of (Nor et al 2012), (Kaur and Kiran, 2014) and controversy towards the result of (Ling et al 2016) and also the EBanking services are having an Standardized indirect effect to the Customer Satisfaction through Security with the value of (0.892) through SEM of AMOS and thereby accepted the alternative hypothesis $(\mathrm{H} 5)$.

\section{CONCLUSION}

As the study has attempted to study the impact of E-banking services on the customer satisfaction especially in Public Sector Banks in India through only limited factors like Responsiveness, Convenience and the Security by selected the 
respondents/customers through simple random sampling technique, further research may be conducted by considering additional factors with large sample size through various other sampling technique. While doing so, the various geographic and topographic areas may be kept in mind through cross sectional study so that many valuable output and findings could be obtained which will give better understanding among the audience universally.

\section{REFERENCE}

Alhawary, S.I.S. and Ahlam Jebreen Ahmad Hussien, A.J.A. (2017). The Impact of Electronic Banking Services on the Customers Loyalty of Commercial Banks in Jordan. International Journal of Academic Research in Accounting, Finance and Management Sciences, 7 (1), 50-63.

Ashtiani, L.H.M.S., Ashtiani, L.M.S., Ahmad, S. and Ashtiani, L. (2017). Evaluate the Effectiveness of Customer Relationship Management in the Banking System (Case Study: Melli Bank of Arak). International Journal of Scientific Study,5(5), p. 381.

Basel, J. A., Ali, and Wan Ahmad Wan Omar,W.A.W. (2016). Role, Challenges and Benefits of Electronic Banking service in Jordan. American Based Research Journal, 5(12), 43-46.

Buddhika, H.K.T. and Gunawardana, (2020). The impact of E-Banking on Customer Satisfaction in Private Commercial Banks, Sri Lanka. Proceedings of the 9th International Conference on Management and Economics - 2020, ICME 2020, 353-378.

Chau, P. (1997). Re-examining a model for evaluating information center success using a structural equation modeling approach. Decision Sciences, 28(2),309-333. https://doi.org/10.1111/j.1540-5915.1997.tb01313.x.

Hammoud, J., Bizri, M.R. and Baba, E.I. (2018). The Impact of E-Banking Service Quality on Customer Satisfaction: Evidence from the Lebanese Banking Sector, SAGE open July-September 1-12.

Hoyle, R.H. (2004). Confirmatory Factor Analysis. Encyclopedia of Social Science Research Methods, 1, 169-175.

Jenifer, D.C.E., and Rao, N.B.C. (2018). A study on Customer Satisfaction towards Service provided by ICICI Bank, Chennai. Indo-Iranian Journal of Scientific Research, 2(3), 225-238.

Johannes, D.V., Indarini and Margaretha,S. (2018). Usability, customer satisfaction, service, and trust towards mobile banking user loyalty. Advances in Social Science, Education and Humanities Research, 186,144-147. 
Joseph, F.H., E., Rolph E.A., Ronald, L.T. and Black C.W.(1998). Multivariate Analysis. New Delhi: Pearson Education.

Kaur, N. and Kiran, R. (2014). Customer Satisfaction and Customer Loyalty in EBanking in India: The Intricacies of Relationship. IOSR Journal of Business and Management, 16 (9):6-13.

Kervin, E. and Mojares, B. (2014).Customer Satisfaction and Loyalty Among Internet Banking Users of Philippine National Bank in Batangas City. Asia Pacific Journal of Multidisciplinary Research, 2(2),41-48.

Kodithuwakku, S. (2018). Impact of Internet Banking on Customer Satisfaction: A Case Study of State Banks in Kandy District. Academy of Social Science Journal, $3(2), 1114-1122$.

Ling, M.G., Fern, S.Y., Boon, K.L. and Huat, S.T. (2016). Understanding Customer Satisfaction of Internet Banking: A Case Study In Malacca. Procedia Economics and Finance, 37, $80-85$.

Maroofi, F. (2013). Factors Affecting Customer Loyalty of Using Internet Banking in Iran. World Applied Sciences Journal, 28 (11),1685-1693.

Moga, M.L., Nor, M.K., Neculita, M. and Khani, N. (2012). Trust and Security in Ebanking Adoption in Romania. IBIMA Publishing, 2012,1-10.

Munir, M.M.M. (2017). An Empirical Study on Risks and Benefits of E-banking in Context of Employee Satisfaction in Rajshahi Division, Bangladesh. Research Reviews: Journal of Social Sciences, 3(3), 149-156.

Narayana, K.V. L., Hari, S. and Paramashivaiah, P. (2013). A Study on Customer Satisfaction towards Online Banking services with reference to Bangalore city. Acme Intellects International Journal of Research in Management, 2(2),1-18.

Ndubisi, N.O. (2006). Relationship marketing and customer loyalty. Marketing intelligence and Planning, 25: 98-106.

Nunnally, J.L. (1978). Psychometric Theory, 2nd ed. New York: Mcgraw-Hill.

Panda, S. K. and Misra, D. P. (2017). Customer Perception on E-Banking: An Empirical Study on Rural Banks in the selected Districts of Odisha. International Journal of Development Research, 7(11), 16588-16592.

Prudon, P. (2015). Confirmatory factor analysis as a tool in research using questionnaires: a critique. Comprehensive Psychology, 4(10):1-18.

Ozuru, H. N., Chikwe, J.E. and Uduma, I. (2010). The use of Traditional payments and electronic payments systems in Nigeria: A discourse; Proceedings of the 11th Annual Conference of International Academy of African Business and Development 
Ramya, S. K., Rajam, M., Usharani, and Sivasubramanian, D. (2013). Customer Loyalty towards E-Banking Services. Journal of Business Management \& Social Sciences Research, 2(9), 41-46.

Rajput, S.U. (2015). Customer Perception on E-Banking Service. Pacific Business Review International. 8(4), 85-94.

Salim, A.A.I.M. (2018). A closer look at the relationship of entry-level bank employees'leadership attributes and customer satisfaction. Journal of Financial Services Marketing, 23,91-103.

Sangeetha, S., and Myilswamy, K. (2020). Customers Satisfaction towards EBanking Services with Special Reference to Coimbatore City. International Journal of Scientific and Technology Research, 9(1), 2742-2753.

Sanli, B. and Hobikoglu, E. (2015). Development of Internet Banking as the Innovative Distribution Channel and Turkey Example. Procedia - Social and Behavioral Sciences, 195,343 - 352. https://doi.org/10.1016/j.sbspro.2015.06.362.

Saravanan, N. and Leelavathi, R. (2020). Impact Of E- Banking Services With Customer Attitude And Satisfaction With Special Reference To Chennai District. European Journal of Molecular \& Clinical Medicine, 7(10), 2585-2596.

Sathiyavany, N., and Shivany, S. (2018). E-Banking Service Qualities, E-Customer Satisfaction, and e-Loyalty: A conceptual Model. The International Journal of Social Sciences and Humanities Invention, 5(6), 4808-4820.

Schober, P., MMedStat, Christa Boer, C. and Schwarte, A.L (2018). Correlation Coefficients: Appropriate Use and Interpretation. Anesthesia \& Analgesia, 126(5),1763-1768.

Sharma, J., Singh, J. and Singh, A. (2020). Impact of E-Banking Service Quality on Customer Satisfaction. International Journal of Recent Technology and Engineering, 8(5),2296-2300.

Singh, P.I. and Bassi, P. (2017). A Review on Customer Satisfaction with Internet Banking in Public and Private Bank. International Journal of Engineering Sciences \& Research Technology, 6 (1), 448-452.

Sun, J. (2005). Assessing goodness of fit in confirmatory factor analysis. Measurement and Evaluation in Counseling and Development, 37,240-256

Sunith, C.K. (2019). Customer Satisfaction in E-Banking Services. International Journal of Business and Management Invention, 8(1),19-24.

Usha, N.P. (2012). Internet banking in India: Risk analysis and adoption in an emerging economy. Indian Streams research Journal, 2(3),1-4.

Yee, Y.B. and Faziharudean, T.M. (2010). Factors Affecting Customer Loyalty of Using Internet Banking in Malaysia. IBIMA Publishing, 2010, 1-21.doi:

$10.5171 / 2010.592297$ 
Zavareh, B.F., Ariff, M.S.M., Jusoh, A., Zakuan, N. and di Bahari, Z.A. (2012). EService Quality Dimensions and Their Effects on ECustomer Satisfaction in Internet Banking Services. Procedia - Social and Behavioral Sciences 40,441-445.

\section{APPENDIX}

Table 1. Details of the parameter estimates of the study

\begin{tabular}{|c|c|c|c|c|c|c|c|}
\hline Latent Factors & Label & $\begin{array}{c}\text { Standardized } \\
\text { Factor } \\
\text { Loading }\end{array}$ & $\begin{array}{l}\text { Cronbach } \\
\text { Alpha } \\
\text { Value }\end{array}$ & $\begin{array}{l}\text { Critical } \\
\text { Ratio } \\
\text { (CR) }\end{array}$ & $\mathrm{R}^{2}$ & $\begin{array}{c}\text { Average } \\
\text { Variance } \\
\text { Extracted } \\
\text { (AVE) }\end{array}$ & $\begin{array}{l}\text { Composite } \\
\text { Reliability }\end{array}$ \\
\hline \multirow{5}{*}{ Responsiveness } & RES1 & 0.574 & & 13.312 & 0.329 & \multirow{5}{*}{0.450} & \multirow{5}{*}{0.943} \\
\hline & RES2 & 0.622 & & 16.544 & 0.387 & & \\
\hline & RES3 & 0.593 & 0.795 & 15.014 & 0.351 & & \\
\hline & RES4 & 0.750 & & 25.809 & 0.563 & & \\
\hline & RES5 & 0.787 & & & 0.619 & & \\
\hline \multirow{4}{*}{ Convenience } & CON1 & 0.751 & & 25.585 & 0.564 & \multirow{4}{*}{0.466} & \\
\hline & CON2 & 0.623 & & 20.668 & 0.388 & & \\
\hline & CON3 & 0.700 & & 17.165 & 0.490 & & \\
\hline & CON4 & 0.649 & 0.792 & * & 0.421 & & 0.925 \\
\hline \multirow{5}{*}{ Security } & SEC1 & 0.716 & & * & 0.513 & \multirow{5}{*}{0.430} & \multirow{5}{*}{0.934} \\
\hline & SEC2 & 0.528 & & 20.690 & 0.279 & & \\
\hline & SEC3 & 0.751 & & 23.101 & 0.564 & & \\
\hline & SEC4 & 0.558 & 0.815 & 12.560 & 0.311 & & \\
\hline & SEC5 & 0.696 & & 14.094 & 0.484 & & \\
\hline \multirow{5}{*}{$\begin{array}{l}\text { Customer } \\
\text { Satisfaction }\end{array}$} & CS1 & 0.837 & \multirow{5}{*}{0.785} & * & 0.701 & & \\
\hline & CS2 & 0.777 & & 27.371 & 0.603 & \multirow{4}{*}{0.554} & \multirow{4}{*}{0.974} \\
\hline & CS3 & 0.830 & & 32.653 & 0.689 & & \\
\hline & CS4 & 0.785 & & 27.599 & 0.616 & & \\
\hline & CS5 & 0.401 & & 32.823 & 0.161 & & \\
\hline
\end{tabular}

Source: Primary Data 
Table 2. Demographic Characteristics of the Respondents

\begin{tabular}{|c|c|c|c|c|}
\hline SI.No & Demographic Characteristics & & Number (n) & $\%$ \\
\hline \multirow[t]{3}{*}{01.} & Gender & Male & 452 & 67.8 \\
\hline & & Female & 215 & 32.2 \\
\hline & & Up to 20 years & 263 & 39.4 \\
\hline \multirow[t]{6}{*}{02.} & Age & $21-35$ years & 305 & 45.7 \\
\hline & & $36-50$ years & 62 & 9.3 \\
\hline & & $>50$ years & 37 & 5.6 \\
\hline & & Illiterate & 86 & 12.9 \\
\hline & & SSLC & 157 & 23.5 \\
\hline & & HSC & 103 & 15.4 \\
\hline \multirow[t]{6}{*}{03.} & Educational Qualification & Graduate & 221 & 33.3 \\
\hline & & Post Graduate & 73 & 10.9 \\
\hline & & Others & 27 & 4.0 \\
\hline & & Public Sector & 127 & 19.0 \\
\hline & & Private Sector & 402 & 60.3 \\
\hline & & Agriculture & 34 & 5.1 \\
\hline \multirow[t]{4}{*}{04.} & Occupation & Business & 84 & 12.6 \\
\hline & & Pensioners & 14 & 2.1 \\
\hline & & Others & 6 & .9 \\
\hline & & Urban & 317 & 47.5 \\
\hline \multirow[t]{4}{*}{05.} & Status of Residential Area & Rural & 296 & 44.4 \\
\hline & & Semi Urban & 54 & 8.1 \\
\hline & & $<1$ year & 92 & 13.8 \\
\hline & & $1-5$ years & 323 & 48.5 \\
\hline \multirow[t]{4}{*}{06.} & Experience with the bank & $6-10$ years & 147 & 22.0 \\
\hline & & $>10$ years & 105 & 15.7 \\
\hline & & Savings Bank & 317 & 47.5 \\
\hline & & Recurring Deposit & 187 & 28.1 \\
\hline \multirow[t]{5}{*}{07.} & Type of Account & Fixed Deposit & 36 & 5.4 \\
\hline & & Current Account & 82 & 12.3 \\
\hline & & Other Account & 45 & 6.7 \\
\hline & & Daily & 29 & 4.3 \\
\hline & & Weekly & 201 & 30.1 \\
\hline \multirow[t]{3}{*}{08.} & Frequency of Visit & Fortnightly & 124 & 18.7 \\
\hline & & Monthly & 46 & 6.9 \\
\hline & & Rarely & 267 & 40.0 \\
\hline
\end{tabular}

Source: Primary Data 
Table 3. Table results showing the association between the factors through Karl Pearson's Correlation

\begin{tabular}{lcccc}
\hline Karl Pearson's Correlation & & & \\
\hline & Responsiveness & Convenience & Security & $\begin{array}{c}\text { Customer } \\
\text { Satisfaction }\end{array}$ \\
Responsiveness & 1 & $0.716^{* *}$ & $0.688^{* *}$ & $0.759^{* *}$ \\
Convenience & 1 & $0.656^{* *}$ & $0.705^{* *}$ \\
Security & & 1 & $0.691^{* *}$ \\
Customer Satisfaction & & & 1 \\
\hline${ }^{* *}$ 1\% level of significance & & & \\
Source: Primary Data & & &
\end{tabular}

Table 4. Details of Regression Coefficient and the Statistics for the Proposed Model of the Study

\begin{tabular}{|c|c|c|c|c|c|c|}
\hline $\begin{array}{l}\text { Factor } \\
\text { (Dependent) }\end{array}$ & $\begin{array}{l}\text { Factor } \\
\text { (Independent) }\end{array}$ & $\begin{array}{l}\text { Regression } \\
\text { Coefficient (B) }\end{array}$ & S.E & $\begin{array}{l}\text { " } \mathrm{t} \text { " test } \\
\text { value }\end{array}$ & $\begin{array}{l}\text { Tolerance } \\
\text { Value }\end{array}$ & $\begin{array}{l}\text { VIF } \\
\text { Value }\end{array}$ \\
\hline \multirow[t]{9}{*}{$\begin{array}{l}\text { Customer } \\
\text { Satisfaction }\end{array}$} & Constant & -0.023 & 0.448 & -0.052 & & \\
\hline & Responsiveness & 0.397 & 0.034 & $11.542^{* *}$ & 0.403 & 2.479 \\
\hline & Convenience & 0.300 & 0.041 & $7.292^{\star *}$ & 0.437 & 2.289 \\
\hline & Security & 0.249 & 0.034 & $7.324^{\star *}$ & 0.472 & 2.120 \\
\hline & $\mathrm{R}^{2}$ Value & 0.658 & & & & \\
\hline & $\begin{array}{l}\text { Adjusted } R^{2} \\
\text { Value }\end{array}$ & 0.656 & & & & \\
\hline & F Value & $424.625^{\star *}$ & & & & \\
\hline & $\begin{array}{l}\text { Number of } \\
\text { Samples }\end{array}$ & 667 & & & & \\
\hline & $\begin{array}{l}\text { Durbin Watson } \\
\text { Test Value }\end{array}$ & 2.037 & & & & \\
\hline
\end{tabular}

